\title{
Professional Development of English Professors in Indian Engineering Colleges: The Need of the Hour
}

\author{
A. Clement ${ }^{1} \&$ T. Murugavel ${ }^{1,2}$ \\ ${ }^{1}$ Saveetha School of Engineering, Saveetha University, Chennai, India \\ ${ }^{2}$ Sri Venkateshwara College of Engineering, Chennai, India \\ Correspondence: A. Clement, ALBA Flats, 78.4, II Main Street (North), Sadasivam Nagar, Madipakkam, \\ Chennai, India. Tel: 919-884-806-118. E-mail: aloyclement@gmail.com
}

\author{
Received: January 22, 2015 Accepted: February 26, 2015 Online Published: April 23, 2015 \\ doi:10.5539/elt.v8n5p132 URL: http://dx.doi.org/10.5539/elt.v8n5p132
}

\begin{abstract}
English has become the language of international business and in this age of globalization, communication skills in the English language are of supreme importance in the professional success of individuals. In India, the percentage of engineering graduates who remain unemployed after graduation steadily increases due to lack of soft skills including the ability to communicate in English. Hence, the major responsibility of enhancing the students' communication skills falls on the shoulders of the English professors. This article aims to find out whether English professors in engineering colleges in Chennai, India are equipped to train engineering students to communicate efficiently by using modern methods of teaching. It has been discovered that many English professors are not aware of the modern teaching methodologies like CLT and haven't heard of English for Specific Purposes. Moreover, many teachers have not attended any pre-service or in-service training programs and there is a huge gap between classroom teaching practices and industry expectations. The survey results have revealed the lack of skills among the professors and the need for professional development programs to improve the efficiency of English teaching.
\end{abstract}

Keywords: professional development, in-service and pre-service training, CLT, ESP, general English, English professors, engineering colleges

\section{Introduction}

Engineering students in India face tough challenges before they are employed in an organization. According to the report, there are 3,345 engineering colleges in India and 1.5 million students graduate every year (Mahajan, 2014). The increasing number of engineering graduates poses a strong challenge in the job market and companies have hardened their recruitment processes due to the overflow of graduates each year. Language proficiency has been playing a major role for years in India and it has become the mandatory skill required for finding a good placement. Bhandari (2014) points out that thousands of unemployed and unemployable engineers have graduated with a degree but without expertise and only 18 to $20 \%$ of them are employable in India. He adds that the educational system doesn't focus on quality and practical application. This is appropriate to language teaching too. Graduates are expected to possess verbal communication skills, presentation skills, written skills along with comprehension skills. Tahem Veer Verma (2014) indicates that while graduates are technically proficient, they not only find it difficult to express their ideas, but also communicate with clients. English is a mandatory paper in most engineering colleges in India with the aim of preparing engineering students for employability. The main objective of this course is to enhance the communicative skills of students so that they become employable graduates. However, many engineering graduates are found to be lacking in English communication skills and the problem of unemployability grows unabated. Hence, it is mandatory to unravel the mystery behind this lack of communication skills and solve the issue of unemployment threat. . Infosys chairman emeritus N R Narayana Murthy has said that the selection criteria for engineering admissions must be changed as the quality of engineers is not up to the mark (The Times of India, 2014).

Chandra (2012), who is a partner with KPMG, has written in his open letter to Indian graduates:

'You are spoiled by the "India growth story"; by an illusion that the Indian education system is capable of producing the talent that we, your companies, most crave; by the imbalance of demand and supply for real 
talent; $;. . .$. and by the law of large numbers in India, which creates pockets of highly skilled people who are justly feted but ultimately make up less than 10 percent of all of you. Well over half of the pre-screened résumés lack the English ability to effectively communicate in business. So the onus, dear reader, is on you-to develop comprehensive English skills, both written and oral'.

In today's Indian job market, it is impossible to find a job suitable to the qualification of engineering graduates as the supply surpasses the demand. Therefore, engineering graduates who are good at English language find jobs that require English language skills i.e. content writers, editors, call centre executives. Hence, English language plays a decisive role in being eligible for a respectable job.

\subsection{The Role of English Professors Working in Engineering Colleges}

India's educational system is more comfortable with the traditional methods of teaching and language teaching is grammar based and teacher oriented. Albert Ryan (2008) points out that professors are comfortable following the traditional methods of teaching in which grammar learning is the most important ingredient and there is less space for activities that trigger spontaneous flow of communication.

ELT conferences in India accentuate technology integrated language teaching, methods of language teaching, learning styles and strategies and evaluation methods. In spite of experts' discussions and paper presentations, there is always a big gap between what is learnt in conferences and what is practiced in classrooms. The excitement of conference participation vanishes within a couple of weeks and teachers tend to return to their old habits of teaching. Everyone agrees that English language professors in engineering colleges play an important role in shaping the language proficiency of students but the reality presents a bleak picture. Various reports and surveys highlight the importance of language skills and the unemployability of Indian graduates over and over again. Though communication skills is the key word of English teaching, many English professors in India are unfamiliar with terms like ESP, CLT and TBLT or do not know the concepts and theories related to these terms. This ignorance is quite rampant as many English professors have completed their post graduation in English literature in which ELT is one of the papers (Albert Ryan, 2008). As far as the communicative language teaching is concerned, India has a long way to go. Though communicative competence is the focus of English courses, the result of English teaching is not quite promising as many professors have no idea about how to implement CLT or TBLT in their classes. In countries like China, Japan and Korea, the spotlight is on communicative competence and the governments have introduced Communicative Language Teaching and have started training their teachers accordingly (IGAWA, n.d.).

Freeman (1996) points out teachers' previous experiences as learners influence the methodology of teaching even after many years and this statement stands true in Indian classrooms. Due to this prevalent grammar based teaching, engineering students whine that they have not learnt any new language skill that is required in their workplaces as the teaching-learning process emphasizes learning grammar without much efforts to strengthening their communication skills (Clement \& Murugavel, 2015). Grammar based language instruction justifies why so many people lost interest in language learning, and are not able to reach fluency in spite of continued efforts (Fotheringham, 2009). In many Asian countries, written exams are the most favored method of assessing the students; therefore the teacher training programs make no sense as teachers are pushed to stick to the traditional methods of teaching. Moreover, teachers are adamant about drill patterns in language classes.

As teachers are not trained in CLT, they blindly follow the methodologies which are primarily teacher-dominated, grammar oriented and exam focused. In India, the major focus is always given to high percentage of marks in exams and it adversely affects the method of English teaching.

It must be understood that it is the teacher who is the centre of the curriculum and without the active participation of the teachers, all changes made in the curriculum design will go waste. Teachers work directly with the students and hence the role of teachers in curriculum design is paramount. Their input is the most necessary ingredient in order to create a strong curriculum. (Zeiger, 2014) According to Richard W. Riley (2014) teachers are the primary creators of opportunities for learning. Unfortunately, the teachers remain mute spectators and are asked to follow the curriculum without any training. Teachers in engineering colleges have not been trained to change the methodology of teaching according to the curriculum objectives and as a result the desired outcome of course is still missing. Though the professors have heard of communication skills, many are ignorant of the methods of teaching. Unless they are willing to unlearn their ingrained attitude towards ELT and are ready to open up to the new skills they have to learn in order to train the students, the grim scenario of unemployability in India will make no progress. Moreover, English professors must be aware that English is learnt for different purposes these days and the purpose of English learning in engineering colleges is to make the prospective engineers competent in communication. Hence, the traditional method of teaching must be done 
away with and professors must be taught the principles and concepts of Communicative Language Teaching \& Task Based Language Teaching. English professors must be trained to accept the new challenges that they must be open to learn new strategies of teaching and adapt themselves according to the needs of the learners.

In many engineering colleges in India, young English teachers are recruited without any pre-service teacher training and they face the harsh reality of classrooms on their own and develop their own methodologies. Language teachers face stiff challenges in classrooms due to heterogeneous student community whose mother tongue is different from one another (Naresh \& Bhattu, 2013).

As the teachers grow old, their teacher-centered approach gets deep rooted in their minds and it becomes too difficult to unlearn the old methodologies. Hence, it creates strong resistance to novel methods of teaching like CLT or TBLT. In addition, there are no serious efforts in introducing pre-service or in-service training programs in any of the engineering colleges. Though the English course is called Technical English or English for Engineering Students, the methods of English for Specific Purposes (ESP) are not followed in English classrooms. In reality, very few English professors in engineering colleges are aware of the differences between general English courses and English for Specific Purposes.

\subsection{General English vs English for Specific Purposes}

Wikipedia defines ESP as 'English for specific purposes (ESP), not to be confused with specialized English, is a sphere of teaching English language including Business English, Technical English, Scientific English, English for medical professionals, English for waiters, English for tourism, English for Art Purposes, etc. Aviation English as ESP is taught to pilots, air traffic controllers and civil aviation cadets who are going to use it in radio communications. ESP can be also considered as an avatar of language for specific purposes'. On the other hand, General language teaching concentrates on the fundamentals of grammar. General English aims to achieve a high standard of everyday English communication skills i.e. Reading, Writing, Listening and Speaking.

\subsection{Qualities of an English Teacher}

Certain procedures are proposed by de Arechaga (2001) to improve the professional competence of a teacher:

- The teacher should be up to date.

- The teacher should engage in knowing his or her own professional activity to better his practice.

- The teacher should mingle with colleagues in showing experience and practice.

- A teacher should be self-directed in her/his trial to improve professionally.

There are characteristics mentioned by Constantinides (2001) that differentiate the professionally competent ESP teacher from other teachers:

- Analytical skills to know his own weaknesses and strength

- Able to plan lessons and utilize the resources available

- Expertise to provide a detailed explanation of her/his subject

- Competent to inspire his students

- Capable of choosing the right materials and various lessons

ESP gives more importance to language in context than on teaching grammar and language structures. In ESP English is not taught as a subject separated from the students' real interests; instead, it is incorporated into a subject matter area important to the learners (Fiorito, 2014).

According to Dudley Evans and St. John (1998), the key roles of an ESP Practitioner are,

- Teacher

- Course designer and materials provider

- Collaborator

- Researcher

- Evaluator

Though the qualities of an ESP teacher is differentiated from general English teachers, all of these qualities are important to all the English teachers as they need to play their roles according to the needs of the learners and environment.

In countries like India, any student who has cleared his higher secondary education can join an engineering 
college as the number of private engineering colleges has grown like mushrooms. Most of these private engineering colleges admit students directly due to availability of seats. This reckless practice of admissions has created major challenge for English professors as many students lack basic English skills which in turn affects the employability. Hence, teachers need to play different roles according to the needs of the heterogeneous learner in their classes.

Due to lack of awareness about ELT practices, the teaching methodologies followed in English classes are insipid in India. As English teaching methods constantly change, English teachers find it a taunting task to meet the needs of the system (Sagner, 2014). Hence, pre-service and in-service training programs are mandatory for English professors in India. Though there have been quite a number of research papers on the challenges of classroom English teaching practices in many Asian countries, there is little research found regarding the English language practice in India especially with respect to the language teaching in engineering colleges. Many English professors still pursue their research in English literature which has nothing to do with English language teaching. In many countries where English is not the mother tongue, English teachers are required to complete a teaching certification course like Delta or CELTA. In India, such certifications are not mandatory and hence the language teaching practice is struggling to cope with the modern trends.

\section{Literature Review-Importance of Professional Development Programs}

Richards and Farrell (2005) noted that in-service training for teachers is important to the long-term development of teachers and success of the programs. As the knowledge base of teaching changes constantly, renewal of professional skills is mandatory to address the new challenges in the teaching-learning process. The need to update the skills in terms of curriculum trends, second language acquisition research, composition theory and practice, technology or assessment is severe. They also point out that classrooms are places where teachers also can learn. The administrators of educational institutions must provide continued professional education.

According to Penny Urr (n.d), many teacher trainees know a lot about theoretical linguistic knowledge, but have no idea on integrating it with practical classroom teaching. Moreover, some of them may know some good teaching ideas but are ignorant of the deployment of group or pairwork in the development of communication techniques. She recommends training courses on the principles of good pedagogy i.e lesson design, activity design, and classroom management. In addition, there must be more integration of theory with practice. Reflection and analysis of practice teaching must be enriched by ideas gained from books and lectures. Besides, there is a need for integration of linguistics and pedagogy.

Brian Tomlinson (n.d) feels that it is assumed that in-service training or short refresher courses are necessary to bring TEFL teachers up to date as the flow of new theories, ideas and techniques are overwhelming for teachers to learn everything independently. He points out that teachers may resist the new ideas as the traditional methods of teaching they have been following for years are discredited. Some teachers feel that these new techniques may become failures in actual classroom setting and they may have to revert to their old methodologies. These courses provide only theoretical information without teaching the ways to apply them in classrooms and many courses are too ambitious to bring in radical change in teacher behavior in a short period of time. In order to make these in-service courses effective, the objectives are to be specific, limited and behavioral and the expertise of the participants must be appreciated and made use of. Most importantly, the course must be experimental and not just theoretical. He suggests that individual classroom observation, constructive feedback, group discussion and planning are vital to achieve the objective of these in-service training.

Martin Parrott (1993) observes that improving teaching skills or awareness of language teaching is not achieved by subscribing to one particular approach or method as there is no right way to teach. Teachers must be aware of their students' dispositions to learn and change their styles according to the needs. They must be aware of their own teaching preferences and predispositions. Professional competence involves 'experimental knowledge' and 'received knowledge' (Wallace, 1991). As per the model, received knowledge refers to acquaintance with "the vocabulary of the subject and the matching concepts, research findings, theories and skills which are widely accepted as being part of the necessary intellectual content of the profession". Experiential knowledge refers to both the knowledge-in-action developed by pre-service teachers through practice and the opportunity to reflect on that knowledge-in-action (Wallace, 1991).

Crookes (1997) has observed that novice teachers are on their own many a time without proper direction. Farrell points out that there is always a gap between pre-service teacher preparation and in-service teacher development. First years of teaching always offer 'reality shock' to many young teachers and they face 'harsh and rude reality of classroom life' (Veenman, 1984).

The professor's proficiency in handling such sessions would highly rely on the orientation they receive from 
experts. This would improve the employability and humanistic faculties of future engineers. Professors need to practice differentiated instruction to suit varying learning styles of students (Tomlinson, 2001). The professors may be trained in pre-service or in-service situations to design suitable lessons or tasks/activities or learning resources and materials to suit this purpose (Hubbard \& Levy, 2006). This shall suit different learning needs of students if the professors follow supportive, co-operative and interactive teaching techniques.

Freeman and Johnson (1998) argue that the foundation of language teacher education has to focus on the activity of' the teaching itself, the teacher who does it, the context in which it is done, and the pedagogy by which it is done'.

According to Cheng and Wang (2003), teacher educators must know the present condition of language teachers and their professional needs. In addition, teacher educators are to know the teachers' knowledge base and their training patterns so that they can be helped to reach their professional goals.

\section{Methodology}

\subsection{Participants, Location, and Instruments Review}

This study was conducted among 40 English professors working in different engineering colleges located in the city of Chennai which is one of the major educational centers in India. Responses were collected through emails and in person. $77.5 \%$ of respondents were female and $22.5 \%$ were male teachers. Out of the 40 professors, 10 had doctorate degrees and 30 were postgraduates. $77.5 \%$ of the respondents were aged between $25-40$ years and $20 \%$ were between 40-60 years. The remaining respondents were between $22-24.75 \%$ of the participants had more than five years of teaching experience in engineering colleges.

A pilot survey was conducted among 10 English professors to assess the accuracy of the instructions to be measured by whether all the participants are able to follow the directions as indicated. The questionnaire was analyzed and modified according to the review of English language experts and participants.

\subsection{Data Analysis}

The format of a typical five-level Likert item was used in the questionnaire:
1) Strongly disagree
2) Disagree
3) Neither agree nor disagree
4) Agree
5) Strongly agree

Data was analyzed quantitatively using SPSS software.

\section{Findings}

The first part of the questionnaire focused on collecting the participants' background details. The second part of the questionnaire aimed at finding the qualifications of the participants. As most of the English professors have Master's degree in English literature, the statement was aimed to find out whether they were trained to teach general English courses or ESP. The third part sought to collect the information of the professors' willingness to update their skills to become more relevant to the needs of the industry.

\subsection{EFL Training During Undergraduate and Post Graduate Studies}

During my undergraduate and post graduate programs, I was trained in EFL methodologies:

\section{Percent}

$\begin{array}{ll}\text { Strongly Disagree } & 17.5 \\ \text { Disagree } & 45.0 \\ \text { Neither agree nor disagree } & 5.0 \\ \text { Agree } & 17.5 \\ \text { Strongly Agree } & 15.0 \\ \text { Total } & 100.0\end{array}$

$62.5 \%$ of respondents disagreed that they were trained to teach English language. $32.5 \%$ of respondents agreed that they were trained in ELT methodologies. This result exposes the lack of training for English professors in language teaching. 


\subsection{ELT Training Certification (TEFL Certificate, DELTA, CELTA)}

I have received ELT training certification:

\section{Percent}

Strongly Disagree

Disagree

Neither agree nor disagree

Agree

Strongly Agree

Total

\section{0}

50.0

5.0

17.5

2.5

100.0

The second statement was intended to find out whether English professors received any authentic training certification in order to teach English language skills. $75 \%$ of professors disagreed that they received any ELT training certification like CELTA or Delta which reveals that most number of professors are ignorant of modern methodologies. It was also found out that many are not aware of these courses as these qualifications are not required to teach English.

\subsection{Knowledge about ESP}

I have read journal papers on ESP and its implementation:

\section{Percent}

$\begin{array}{ll}\text { Disagree } & 40.0 \\ \text { Neither agree nor disagree } & 7.5 \\ \text { Agree } & 40.0 \\ \text { Strongly Agree } & 12.5 \\ \text { Total } & 100.0\end{array}$

Only $42.5 \%$ of respondents accepted that they have read about ESP though the participants teach English for engineers. This result reveals that many professors are not trained to teach English for Specific Purposes and they teach general English using grammar-oriented methods.

\subsection{Pre-Service Training Program}

I attended pre-service training program before teaching English to engineering students:

$\begin{array}{ll} & \text { Percent } \\ \text { Strongly Disagree } & 17.5 \\ \text { Disagree } & 42.5 \\ \text { Neither agree nor disagree } & 7.5 \\ \text { Agree } & 30.0 \\ \text { Strongly Agree } & 2.5 \\ \text { Total } & 100.0\end{array}$

$60 \%$ of participants responded that they didn't attend any pre-service training after they joined engineering colleges. Some of them had experience teaching English in schools \& Arts and Science colleges but they were recruited in engineering colleges without any pre-service training or introduction to the curriculum.

\subsection{In-Service Teacher Training}

I have participated in professional development programs:

$\begin{array}{ll} & \text { Percent } \\ \text { Strongly Disagree } & 12.5 \\ \text { Disagree } & 42.5 \\ \text { Neither agree nor disagree } & 5.0 \\ \text { Agree } & 30.0\end{array}$


$\begin{array}{ll}\text { Strongly Agree } & 10.0 \\ \text { Total } & 100.0\end{array}$

$40 \%$ of respondents agreed that they attended in-service training programs to teach English language relevant to employability skills of engineering students. Others have absolutely no training with respect to teaching English to engineering students or communication skills which are mandatory for students' workplace success. No serious efforts have been taken to understand the need and train English professors who play a crucial role in enhancing the employment prospects of students.

\subsection{Awareness of Language Skills Required}

I am aware of English skills required for employability:

\section{Percent}

$\begin{array}{ll}\text { Strongly Disagree } & 5.0 \\ \text { Disagree } & 45.0 \\ \text { Neither agree nor disagree } & 17.5 \\ \text { Agree } & 17.5 \\ \text { Strongly Agree } & 15.0 \\ \text { Total } & 100.0\end{array}$

$50 \%$ of respondents disagreed that they are aware of English for employability or the language skills needed to carry out the responsibilities. This result has exposed the big gap between the industry and academia. No serious steps have been taken to bridge the gap or educate the English professors regarding the language skills essential for employability or work place success.

\subsection{Need for ESP Training Program for English Professors}

I will be able to play an effective role if workshops on ESP courses are conducted:

\section{Percent}

$\begin{array}{ll}\text { Disagree } & 2.5 \\ \text { Agree } & 47.5 \\ \text { Strongly Agree } & 50.0 \\ \text { Total } & 100.0\end{array}$

$97.5 \%$ of respondents agree that they will be able to play a more effective role if training programs on ESP are conducted on a regular basis. In fact, many of them asked the researcher to explain ESP and the methods.

\subsection{Workshops on Communicative Language Teaching and Task Based Language Teaching}

I need to participate in training programs to learn methods of CLT and TBLT:

$$
\text { Percent }
$$

$\begin{array}{ll}\text { Disagree } & 5.0 \\ \text { Agree } & 62.5 \\ \text { Strongly Agree } & 32.5 \\ \text { Total } & 100.0\end{array}$

$95 \%$ of participants have agreed they need to undergo training in language methodologies like CLT and TBLT. It has to be noted that the researcher had to explain the terms like CLT or TBLT. This result has accentuated the need for radical overhaul of language teaching methods in engineering colleges.

\subsection{Attitude towards the Recommended Syllabus}

I feel bored to teach the recommended syllabus as it is insipid:

$\begin{array}{ll} & \text { Percen } \\ \text { Strongly Disagree } & 7.5 \\ \text { Disagree } & 30.0 \\ \text { Neither agree nor disagree } & 17.5\end{array}$




\begin{tabular}{lc} 
Agree & 30.0 \\
Strongly Agree & 15.0 \\
Total & 100.0 \\
45\% of respondents have agreed that they \\
4.10 Relevance of Recommended Course \\
\multicolumn{2}{c}{ Percent } \\
Strongly Disagree & 12.5 \\
Disagree & 15.0 \\
Neither agree nor disagree & 12.5 \\
Agree & 50.0 \\
Strongly Agree & 10.0 \\
Total & 100.0
\end{tabular}

$60 \%$ of participants agreed that the syllabus recommended for engineering students is relevant to industry expectations and $27.5 \%$ of respondents disagreed.

\subsection{Industry-Institution Interaction}

There must be regular interaction between industry professionals and English professors to understand the language skills required:

$\begin{array}{ll} & \text { Percent } \\ \text { Strongly Disagree } & 2.5 \\ \text { Disagree } & 5.0 \\ \text { Neither agree nor disagree } & 15.0 \\ \text { Agree } & 32.5 \\ \text { Strongly Agree } & 45.0 \\ \text { Total } & 100.0\end{array}$

$77.5 \%$ of respondents agreed that industry-academia interaction and training programs are necessary to understand the business English skills.

\subsection{Need for Skill Update}

I need to update my skills with respect to modern teaching methodologies:

$$
\text { Percent }
$$

Strongly Disagree $\quad 2.5$

Agree $\quad 32.5$

Strongly Agree $\quad 65.0$

Total $\quad 100.0$

$97.5 \%$ of participants agreed that they need to update their teaching methodologies.

4.13 Need for Pre-Service and In-Service Training

\section{Percent}

Disagree $\quad 7.5$

Neither agree nor disagree $\quad 5.0$

Agree $\quad 52.5$

Strongly Agree $\quad 35.0$

Total 100.0

$87.5 \%$ of members responded that they need in-service training in order to improve their teaching methods. 


\section{Discussions}

English language teaching methods change according to the new dimensions and demands of the modern world and it is the responsibility of all teachers to keep themselves up-to-date to face these challenges. Like any other profession, teachers need to transform themselves through research and continuous professional development programs. This study has highlighted the dire need of overhauling the world of ELT in India. Many newspaper articles and surveys have accentuated the language skills development of engineering graduates; however, there are a very few articles that have shed light on the professional development needs of English professors working in engineering colleges. Teachers need to expand their knowledge and skills persistently in order to break the monotony of classroom teaching (Mizell, 2010). They need to learn the methods of teaching that are followed all around the world to empower themselves. The accurate number of language teaching methods are not verified yet (Kumaravdivelu, 2006). If English teachers are trained in all these methods, they will be able to adapt their teaching styles according to the needs and demands of the learners. They must know the different roles they have to play and be aware why they have to do so. Learners show interest in learning English not to speak like native speakers, but to get a job, to understand the information available in the Internet and to communicate to their peers in office and their counterparts in English speaking countries (Renandya, 2012). Therefore, English professors must understand that communicative competence is the objective of their teaching in engineering colleges so that engineering graduates will be empowered to face their interviews and workplace challenges without ambiguity and fear. Renandya (2012) points out that teachers need to assess themselves, their current roles and reflect on the demands of teaching in the modern world.

As many professors are not exposed to the Communicative Language Teaching methods as per the survey results, it is necessary to introduce training programs that will mould the teachers to break the traditional approaches of language teaching. They must be aware that the world of ELT is changing every day and they can't afford to lag behind. Critical assessment of their pedagogical practices is the need of hour and they have to keep themselves updated to these modern practices followed in most parts of the world. Unlike the traditional approaches where the emphasis is on teacher, CLT recommends that the teacher has to become a facilitator and monitor and students are to become comfortable working in groups. The important features of CLT (Richards, 2006) are,

- Making real communication

- Providing opportunities to experiment language

- Being more patient with the learners' errors

- Both accuracy and fluency are given importance

- Equal importance to listening, speaking, reading and writing

- Finding out the grammar rules without teacher's assistance

The features of CLT are quite relevant to the needs of engineering graduates in India. Though the traditional methods of teaching cannot be uprooted from the minds of the teachers, exposure to CLT will help them to train students towards communicative competence which is one of the most crucial expectations of Indian employers. As both fluency and accuracy are important to language learners, professors will be able to differentiate the two aspects of teaching and implement the methods accordingly. Through teacher education, teachers' beliefs can be reinforced and teachers will learn how to implement their beliefs into practice (Borg, 2011). Many a time experienced teachers are too resistant to accept that they are to be trained but in reality what they say they do in the classroom and what they actually do are different. Though they claim they use student-centered methods, they still follow the teacher-dominated approaches (Farrell \& Lim, 2005).

If new teachers are recruited without any pre-service training, they will face the harsh reality of classrooms and may feel disheartened to teach English. If a new teacher doesn't understand the need of engineering students and stick to the grammar-oriented teaching methods, the gap between the students and teachers will become huge and students will lose interest in learning English. According to The CAELA Guide for Adult ESL Trainers (2007), the following are the ten characteristics of a good teacher:
1) Clear goals and objectives
2) Knowledge of ESL concepts and theories
3) Assessment of needs
4) Awareness of adult learners
5) Task based teaching methodologies 
6) Good communication skills

7) Time management

8) Rapport building

9) Questioning skills

10) Teamwork

These skills must be taught to the English professors in order to be more specific to the needs of the learners and efficient in language teaching methods. The ELT landscape in India needs a revival to upgrade the language skills of engineering students and it is achievable only by convincing the professors to transform themselves through systematic and rigorous training programs.

\section{Conclusion}

This study highlighted the importance of Communicative Language Teaching methods in order to enhance the language skills of engineering students. Students can become more proficient only if the professors are equipped with knowledge of modern teaching methods and theories. Even if the curriculum is revised according to the expectations of the industry, the implementation of the program lies in the hands of the professors who work with the students directly. Moreover, not many research articles are found in India regarding the need for professional development programs for English professors. Hence, it is expected that the findings of this study may help address this gap so that professors will be equipped to train the engineering graduates for their successful careers.

\section{References}

Arechaga, G. (2001). Article 69: Teacher development-Awareness, and sharing. By Graciela Miller de Arechaga. Eltnewsletter.com. Retrieved December 29, 2014, from http://www.eltnewsletter.com/back/ August2001/art692001.htm

Bhandari, R. (2014). How to make engineers in India employable? NextBigWhat. Retrieved December 26, 2014, from http://www.nextbigwhat.com/make-engineers-india-employable-297/

Borg, S. (2011). The impact of in-service teacher education on language teachers' beliefs. Science Direct-SYSTEM, 39, 378. http://dx.doi.org/10.1016/j.system.2011.07.009

Richards, J. C. (2006). Communicative language teaching today (1st ed., p. 13). New York, USA: Cambridge university press.

Center for adult English language acquisition. (2007). The CAELA guide for adult ESL trainers. Washington, DC: Center for applied Linguistics.

Chandra, M. (2012). An open letter to India's graduating classes. India Ink. Retrieved December 26, 2014, from http://india.blogs.nytimes.com/2012/05/23/an-open-letter-to-indias-graduating-classes/?_r=0

Cheng, L., Ren, S., \& Wang, H. (2003). Pre-service and in-service teacher education of secondary English language teachers in China. TEFL Web Journal, 2(1), 1-14. Retrieved September 25, 2003, from http://www.teflweb-j.org/v2n1/v2n1.htm

Clement, A., \& Murugavel, T. (2015). English for Employability: A case study of the English language training need analysis for engineering students in India. English language teaching, 8(2). http://dx.doi.org/10.5539/elt.v8n2p116

Constantinides, M. (2001). Hall of fame teachers. ELT News, 11, 1-7.

Dudley-Evans, T., \& St. John, M. (1998). Developments in ESP. Cambridge, U.K.: Cambridge University Press.

Farrell, T., \& Lim, P. (2005). Conceptions of grammar teaching: A case study of teachers' beliefs and classroom practices. TESL-EJ, 9(2). Retrieved from http://www.tesl-ej.org

Fiorito, L. (2014). Teaching English for specific purposes (ESP). Retrieved December 18, 2014, from http:/www.usingenglish.com/articles/teaching-english-for-specific-purposes-esp.html

Fotheringham, J. (2009). Why grammar-based instruction is bunk. Language Mastery. Retrieved December 26, 2014, from http://12mastery.com/blog/linguistics-and-education/methods/why-grammar-based-instructionis-bunk

Freeman, D., \& Johnson, K. E. (1998). Reconceptualizing the knowledge-base of language teacher education. TESOL Quarterly, 32, 397-417. 
Freeman, D., \& Richards, J. (1996). Teacher learning in language teaching. NY: Cambridge University Press.

Igawa, K. (2008). Professional development needs of EFL teachers practicing in Japan and Korea. Shiten'nojikokusaibukkyodaigaku Bulletin, 45, 432. Retrieved from https://www.shitennoji.ac.jp/ibu/images/toshokan/kiyo45-21.pdf

Kumaravadivelu, B. (2006). Understanding language teaching. Mahwah, N.J.: Lawrence Erlbaum Associates.

Mahajan, A. (2014). 1.5 Million engineering pass outs in India every year, fewer getting hired. Retrieved December 30, 2014, from http://dazeinfo.com/2014/10/28/1-5-million-engineering-pass-outs-india-everyyear-fewer-getting-hired-trends/

Mizell, H. (2010). Why professional development matters (1st ed., p. 3). United States of America: Learning Forward. Retrieved from http://www.leaningforward.org

Naresh, A., \& Bhattu, D. (2013). Avid demand of English language skills to engineering students in Andhra Pradesh for enhancing employability. International journal of English: Literature, language and skills, 2(3), 139.

Renandya, W. (2012). Teacher roles in EIL. The European journal of applied Linguistics and TEFL, 1(2), 66-67.

Riley, R. (2014). Yale National Initiative-mobile version. Teachers.yale.edu. Retrieved December 30, 2014, from http://teachers.yale.edu/oncommonground/index.php?skin=m\&page $=01 / 02$

Ryan, A. (2008). Enginneing English: A critical evaluation (Ph.D). Annamalai University, India.

The Times of India. (2014). Let's nurture 'soft' power. The Times of India. Retrieved from http://timesofindia. indiatimes.com/home/education/news/Lets-nurture-soft-power/articleshow/38776730.cms

The Times of India. (2014). Poor quality of students entering IITs: Narayana Murthy. The Times of India. Retrieved from http://timesofindia.indiatimes.com/india/Poor-quality-of-students-entering-IITs-NarayanaMurthy/articleshow/10217469.cms

Tomlinson, B. (1986). In-Service TEFL-Is it worth the risk? The Teacher Trainer. Retrieved from http://www.ttjournal.co.uk/index.php?page=back_articles

Urr, P. (1986). In language teaching, which is more important: Language or teaching? The Teacher Trainer. Retrieved from http://www.tttjournal.co.uk/uploads/File/back_articles/In_Language_Teaching.pdf

Zeiger, S. (2014). Role of teachers in the curriculum process. Work-Chron.com. Retrieved December 26, 2014, from http://work.chron.com/role-teachers-curriculum-process-5344.html

\section{Copyrights}

Copyright for this article is retained by the author(s), with first publication rights granted to the journal.

This is an open-access article distributed under the terms and conditions of the Creative Commons Attribution license (http://creativecommons.org/licenses/by/3.0/). 